\title{
Masa Depan Industri Pariwisata Kota Palangka Raya (Perspektif dan Solusinya)
}

\author{
Trecy E. Anden \\ Fakultas Ekonomi dan Bisnis, Universitas Palangka Raya \\ Email : trecyanden01@gmail.com
}

\begin{abstract}
Abstrak
Industri pariwisata merupakan penggerak perekonomian secara nasional, regional maupun lokal. Sebagai salah satu sumber pendapatan asli daerah (PAD) Kota Palangka Raya, sektor ini mendapat perhatian prioritas. Sejak 10 tahun terakhir berkembang industri pariwisata mengalami perkembangan dan pertumbuhan yang cukup baik. Sektor ini mampu mendongkrak pertumbuhan PDRB pada lapangan usaha; perdagangangn. hotel dan restoran. Namun dilihat dari sisi pertumbuhan kunjungan wisatawan masih didominasi kunjungan wisatawan lokal, kunjungan wisatawan mancanegara belum tergarap dengan baik. Beberapa permasalahan, tantangan, dan hambatan dialami dalam pengembangan industri pariwisata. Kondisi ini merupakan manifestasi untuk perbaikan serta bahkan menjadi suatu dilema yang harus dikelola dengan harmonis. Masa depan industri pariwisata Kota Palangka Raya memiliki prospek yang baik dapat diantisipasi dengan memperhatikan faktor-faktor yang berpengaruh. Penelitian dilakukan pada kecamatan-kecamatan yang memiliki potensi wisata alam (ecotourism), menggunakan metode penelitian deskriptif kualitatif dan kunatitif dan analias SWOT. Dari sisi perekonomian, sektor pariwisata Kota Palangka Raya meiliki masa depan yang cerah. Tingkat pertumbuhan PDB, perdagangan, hotel dan restoran peran sektor pariwisata sebagai kontributor pendapatan nomor urut 3.
\end{abstract}

Kata Kunci : Industri Pariwisata, masa depan, Kota Palangka Raya

\begin{abstract}
The tourism industry is a driver of the economy nationally, regionally and locally. As one source of local revenue (PAD) city of Palangka Raya, this sector received priority attention. Since the last 10 years developing the tourism industry and has developed a fairly good growth. This sector could boost GDP growth in the field of business; perdagangangn. hotels and restaurants. But seen from the growth in tourist arrivals is still dominated by local tourist arrivals, tourist arrivals have not been well explored. Some of the problems, challenges and constraints experienced in the development of the tourism industry. This condition is a manifestation of improvement and even become a dilemma that must be managed in harmony. The future of the city of Palangka Raya tourism industry has good prospects can be anticipated by considering the factors that influence. The study was conducted in the districts that have the potential of nature tourism (ecotourism), using descriptive qualitative research methods and kunatitif and SWOT analisis. In terms of the economy, the tourism sector of the city of Palangka Raya has particularly bright future. The growth rate of GDP, trade, hotel and restaurant sector the role of tourism as a revenue contributor serial number 3 .
\end{abstract}

Keywords : Tourism Industry, the future, the city of Palangkaraya

\section{Pendahuluan}

Indonesia sebagai salah satu negara di dunia mengandalkan pariwisata sebagai sumber devisa negara, memiliki berbagai daerah sebagai tujuan wisata bagi wisatawan di dunia. Kota Palangka Raya sebagai salah satu wilayah yang ada di Pulau Kalimantan, merupakan pulau yang memiliki daya tarik dan keunikan tersendiri terkenal dengan hutan hujan tropis dan keaneka ragaman flora dan fauna (LPPM, 2012) . Kota Palangka Raya sering mendapat kunjungan wisatawan manca negara dengan berbagai alasan. Sebagai penyumbang pendapatan asli daerah, telah dibangun prasarana maupun sarana pariwisata sesuai program pembangunan pemerintah daerah.

Pembangunan industri pariwisata di Kota Palangka Raya pada hakekatnya merupakan upaya untuk mengembangkan, memanfaatkan obyek dan daya tarik wisata yang terdiri dari kekayaan alam 
yang indah, keragaman flora dan fauna, kemajemukan seni budaya, peninggalan sejarah dan purbakala. Oleh karena itu, industri pariwisata Kota Palangka Raya harus menjadi prioritas utama dalam pengembangan dan pengelolaan dengan tujuan mampu mempengaruhi wisatawan untuk

melakukan kunjungan wisata dan memberikan kontribusi bagi daerah, tertutama sebagai sumber pendapatan daerah dan menjadi salah satu daerah tujuan wisata (DTW) di Provinsi Kalimantan Tengah.

Sejak dibentuknya Dinas Kebudayaan Pariwisata Kota Palangka Raya tahun 2005 dan sekaligus dicanangkannya tahun kunjungan wisata. Pemerintah Kota Palangka Raya telah merencanakan dan mengimplementasikan bebagai program dan kegiatan di sektor pariwisata. Sejalan dengan dinamika, gerak perkembangan industri pariwisata telah merambah ke dalam berbagai terminologi seperti, sustainable tourism development, village tourism, ecotourism, merupakan pendekatan pengembangan kepariwisataan.

Pariwisata (ecotourism), budaya dan kuliner, merupakan salah satu bentuk industri pariwisata yang belakangan ini menjadi tujuan dari sebagian besar masyarakat. Pariwisata yang memberikan "suguhan" kepada wisatawan berupa keindahan alam seperti hutan alam, susur sungai, danau, keanekaragaman hayati dan pesona alami dan lainnya. Kota Palangka Raya pada dasarnya memiliki banyak potensi wisata yang dapat dikembangkan sebagai obyek wisata rekreatif. Namun keterbatasan dalam pengelolaan dan pengembangan lebih lanjut menyebabkan daya tarik pariwisata yang ada belum dapat ditangani secara serius. Upaya telah dilakukan, sesuai dengan kemampuan dan dana yang terbatas untuk mewujudkan adanya suatu obyek wisata yang layak dan mampu menawarkan kenyamanan secara umum.

Dalam perkembangannya, selalu ada faktor yang menghambat, dan bagaimana jika hal ini terus terjadi, bagaimana dapat melihat industri pariwisata Kota Palangka Raya di masa yang akan datang, ini yang menarik penulis, solusi apa yang akan dilakukan untuk menangkal beberapa pengaruh, agar pengembangan industri pariwisata Kota Palangka Raya tetap eksis sepanjang zaman. Permasalahan yang dihadapi pariwisata Kota Palangka Raya ke depan, adalah seperti menggali kunjungan wisata baik domestik maupun manca negara, sumber daya, daya dukung, daya tahan yang dengan potensi alam dan lahan yang luas diharapkan masih mampu membentengi kelestarian alam yang dimiliki.

\section{Perumusan Masalah}

Adapun yang menjadi perumusan masalah penelitian ini adalah:

1. Bagaimana pengembangan industi Kota Palangka Raya dimasa yang akan datang, dapat ditumbuh kembangkan?

2. Bagaimana kebijakan pemerintah dalam perencanaan maupun implementasi kegiatan pengembangan industi pariwisata Kota Palangka Raya bersinergi?

\section{Tujuan Penelitian}

1. Tujuan dari penelitian ini adalah: menemukan solusi pengembangan industri pariwisata dimasa mendatang.

2. Menentukan kebijakan Pemerintah Kota Palangka Raya dalam pengembangan industri pariwisata dimasa mendatang.

\section{Manfaat Penelitian}

Manfaat penelitian ini adalah:

1. Memberi masukan bagi pengembangan akademis mengenai pengembangan industri pariwisata yang dapat meningkatkan kesejahteraan masyarakat. 
2. Memberi masukan bagi Pemerintah Kota Palangka Raya dalam penerapan dan membangun kebijakan dalam pengembangan industri pariwisata.

\section{Batasan Penelitian}

Titik berat atau fokus penelitian ini adalah pada pengembangan dan solusi industri pariwisata Kota Palangka Raya dimasa mendatang.

\section{Tinjauan Pustaka}

Kajian teori: digunakan adalah dengan pendekatan konsep pembangunan pariwisata berkelanjutan WTO, dan teori pertumbuhan Rostow. Menurut Murphy 1985, Pariwisata adalah keseluruhan dari elemen-elemen terkait (wisatawan, daerah tujuan wisata, perjalanan, industri, dan lain-lain ) yang merupakan akibat dari perjalanan wisata, sepanjang perjalanan tersebut tidak permanen; dan The World Tourism Organisation (WTO) memberi batasan teknis bahwa: "Tourism comprises the activities of persons, travelling to and staying in place outside their usual envirornent for not more than one consecutive year for leisure business and other purpose" (Richardson dan Fluker dalam Pitana, 2004).

\section{Pengertian Pariwisata}

Pariwisata lebih populer dan banyak dipergunakan dibanding dengan terjemahan yang seharusnya dari istilah tourism, yaitu turisme, Terjemahan yang seharusnya dari tourism adalah wisata. Yayasan Alam Initra Indonesia (1995) membuat terjemahan tourism dengan turisme. Di dalam tulisan ini dipergunakan istilah pariwisata yang banyak digunakan oleh para rimbawan, mempergunakan istilah pariwisata untuk menggambarkan adanya bentuk wisata yang baru muncul pada dekade delapan puluhan. Pengertian tentang pariwisata mengalami perkembangan dari waktu ke waktu. Namun, pada hakekatnya, pengertian pariwisata adalah suatu bentuk wisata yang bertanggungjawab terhadap kelestarian area yang masih alami (natural area), memberi manfaat secara ekonomi dan mempertahankan keutuhan budaya bagi masyarakat setempat. Atas dasar pengertian ini, bentuk pariwisata pada dasarnya merupakan bentuk gerakan konservasi yang dilakukan o!eh penduduk dunia. Eco-traveler ini pada hakekatnya konservasionis. The Ecotourism Society (1990) mendefinisikan pariwisata sebagai berikut:

"Pariwisata adalah suatu bentuk perjalanan wisata ke area alami yang dilakukan dengan tujuan mengkonservasi lingkungan dan melestarikan kehidupan dan kesejahteraan penduduk setempat“.

\section{Peranan obyek pariwisata}

Pariwisata dapat dipergunakan sebagai katalisator dari kegiatan pembangunan, kepariwisataan merupakan mata rantai panjang yang dapat menggerakkan bermacam-macam kegiatan dalam kehidupan masyarakat.

\section{Obyek Pariwisata}

Darmadjati dalam Ediwarsyah (1987) memberi batasan tentang pengertian obyek pariwisata adalah :

"Pada garis besarnya berwujud obyek, barang-barang mati atas statis, baik yang diciptakan oleh manusia sebagai hasil seni budaya, atau yang berupa gejala-gejala alam yang memiliki daya tarik kepada para wisatawan untuk mengunjunginya agar dapat menyaksikan, mengagumi, menikmati sehingga terpenuhi rasa kepuasan wisatawan-wisatawan itu, sesuai dengan motif kunjungannya". Menurut Undang-undang Republik Indonesia Nomor 10 Tahun 2009 tentang Kepariwistaan, obyek pariwisata adalah pewujudan dari ciptaan Tuhan, tata hidup, seni budaya, sejarah bangsa dan tempat serta keadaan alam yang mempunyai daya tarik untuk kunjungan wisata. 


\section{Peranan Obyek Pariwisata}

Di atas telah dijelaskan pengertian peranan adalah suatu tingkatan kedudukan atau tugas utama yang harus dilaksanakan yang dilakukan oleh manusia dalam melaksanakan suatu kegiatan dengan berbagai cara sehingga dapat menjadi keadaan yang lebih baik dari semula atau dijadikan banyak, diluaskan, diperindah atau dipelihara keadaan obyek tetap lestari. Bila dihubungkan dengan pengertian obyek pariwisata, maka yang di maksud dengan peranan obyek pariwisata adalah suatu tingkatan kedudukan atau tugas yang harus dilaksanakan manusia untuk memelihara, mengembangkan, meluaskan, memperindah, menambah fasilitas yang ada di obyek pariwisata, dengan tujuan untuk menarik minat orang berkunjung ke obyek pariwisata.

Obyek wisata

Obyek wisata merupakan potensi yang menjadi pendorong kehadiran wisatawan ke suatu daerah tujuan wisata. Dalam kedudukannya yang sangat menentukan itu maka obyek wisata harus di rancang dan di bangun atau di kelola secara profesional sehingga dapat menarik wisatawan untuk datang. Membangun suatu obyek wisata harus di rancang sedemikian rupa berdasarkan kriteria yang cocok dengan daerah wisata tersebut. Obyek wisata umumnya berdasarkan pada :

a. Adanya sumber daya yang dapat menimbulkan rasa senang, indah, nyaman dan bersih.

b. Adanya aksesbilitas yang tinggi untuk dapat mengunjunginya.

c. Adanya ciri khusus/spesifikasi yang bersifat langka.

d. Obyek wisata alam memiliki daya tarik tinggi karena keindahan alam pegunungan, sungai, pantai, pasir, hutan, dan sebagainya.

e. Obyek wisata budaya mempunyai daya tarik tinggi karena memiliki nilai khusus dalam bentuk atraksi kesenian, upacara-upacara adat, nilai luhur yang terkandung dalam suatu obyek buah karya manusia pada masa lampau.

\section{Metode Penelitian}

Penelitian ini dilakukan di Kota Palangka Raya, dengan metode survei untuk memperoleh informasi-informasi dan data dari gejala, serta mendapatkan keterangan dengan menggunakan pedoman questioner. Daerah yang dipilih sebagai objek penelitian adalah Kecamatan Jekan Raya, Kecamatan Sabangau, Kecamatan Rakumpit, Kecamatan Tangkiling dengan pertimbangan bahwa di daerah ini memiliki potensi pariwisata keunikan hutan hujan tropis, flora dan fauna.

Untuk memenuhi tujuan penelitian maka data dikumpulkan melalui survei lapangan dari informan-informan, studi perpustakaan dan sumber-sumber relevan. Informan dalam penelitian ini berasal dari pelaku kebijakan yaitu Kantor Dinas Pariwisata dan Ekonomi Kreatif Kota Palangka Raya, pelaku pariwisata, serta masyarakat pemerhati pariwisata.

Penelitian ini menggunakan metode kualitatif dan kuantitatif deskriptif dengan menyajikan dalam bentuk tabel, uraian dan analisis. Penggunaan pendekatan kuantitatif deskriptif secara bersamaan dimaksudkan untuk memberikan informasi yang maksimal (Singarimbun, 1990).

\section{Hasil dan Pembahasan}

\section{Gambaran Umum Kota Palangka Raya Kini dan Ke depan}

Jika melihat dari pengertian pariwisata itu sendiri, maka munculnya pariwisata itu sendiri adalah akibat dilakukan kunjungan wisata ke objek wisata dan tujuan-tujuan lain, seperti halnya wisata alam (ecotourism). Adanya kunjungan tersebut dapat dijadikan salah satu indikatornya untuk melihat bagaimana perkembangan industri pariwisata suatu daerah. Besarnya jumlah kunjungan dan lamanya tinggal wisatawan di Kota Palangka Raya dapat dijadikan indikator melihat perkembangan atau pertumbuhan sektor pariwisata Kota Palangka Raya ke depan. 
Pertumbuhan kunjungan wisatawan ke Kota Palangka Raya dalam kurun waktu 5 tahun terakhir yakni pada tahun 2009 sampai dengan tahun 2013, dengan mengutip data yang disampaikan dalam Dinas Kebudayaan dan Pariwisata Kota Palangka Raya Dalam Angka (2013) menunjukan trend yang meningkat walaupun tidak signifikan dari 94.074 orang pada tahun 2009 dan mencapai 95.116 orang di tahun 2011 didominasi kunjungan wisatawan lokal.

Product Domestic Regional Brutto (PDRB) untuk sektor perdagangan, hotel dan restoran; Rp. 505.447,72 milyar tahun 2009, Rp. 572.470,91 tahun 2010, Rp. 672.123,11 tahun 2011, Rp, 790.676,43 milyar tahun 2012 dan Rp. 912.206,22 milyar tahun 2013. Sumbangan terhadap PDRB Kota Palangka Raya terus mengalami peningkatan, serta laju pertumbuhan menunjukan sektor perdagangan, hotel dan restoran di tahun 2010 menempati angka pada urutan ke 2 setelah sektor pengangkutan dan komunikasi, di tahun 2011 menempati urutan 3 setelah sektor pengangkutan dan komunikasi, dan di tahun 2013 di urutan ke 3 setelah sektor pengangkutan dan komunikasi. Bila melihat pertumbuhan Lapangan Usaha Sektor Perdagangan, Hotel dan Restoran dari tahun 2009 sampai dengan 2013, berdasarkan data BPS 2013, seperti data dalam Tabel 1.

Tabel.1 PDRB (Milliar Rupiah)

\begin{tabular}{|c|c|c|c|c|c|}
\hline Lapangan usaha & 2009 & 2010 & 2011 & 2012 & 2013 \\
\hline 1. Pertanian dim arti luas & $212.494,44$ & $222.976,89$ & $237.140,65$ & $258.718,63$ & $289.746,42$ \\
\hline 2. Pertambangan dan galian & $53.613,53$ & $58.455,34$ & $64.794,34$ & $66.093,39$ & $76.923,81$ \\
\hline 3. Industri Pengolahan & $166.354,20$ & $177.961,26$ & $187.319,08$ & $202.560,05$ & $227.163,49$ \\
\hline 4. Listrik gas, air bersih & $87.243,92$ & $96.210,68$ & $108.559,11$ & $125.186,88$ & $138.028,47$ \\
\hline 5. Bangunan & $222.500,38$ & $239.403,02$ & $267.219,29$ & $309.109,30$ & $361.565,72$ \\
\hline 6. Perdag Hotel \& Restoran & $505.447,72$ & $572.470,91$ & $672.123,11$ & $790.676,43$ & $912.206,22$ \\
\hline 7. Pengangkutan dan Kom. & $623.164,48$ & $681.309,67$ & $750.034,44$ & $837.850,58$ & $963.710,53$ \\
\hline $\begin{array}{l}\text { 8. Keuangan, Pesewaan, jasa } \\
\text { Perusahaan }\end{array}$ & $203.541,40$ & $309.924,69$ & $391.246,13$ & $467.841,28$ & $562.378,97$ \\
\hline 9. Jasa-jasa & $1.033 .501,40$ & $1.255 .442,56$ & $1.472 .551,95$ & $1.677 .644,37$ & $1.944 .006,95$ \\
\hline $\begin{array}{l}\text { Produk Domestik Regional } \\
\text { Bruto }\end{array}$ & $3.107 .861,47$ & $3.614 .155,01$ & $4.147 .987,15$ & 4.735 .680 .80 & $5.475 .730,58$ \\
\hline
\end{tabular}

Sumber : Kota Palangka Raya Dalam Angka, 2011. 2012 dan 2013

Pendapatan Asli Daerah (PAD) untuk sektor industri pariwisata sejak tahun 2008 sebesar Rp. 1.611.901.131,-- mengalami kenaikan sangat signifikan pada tahun 2011 menjadi sebesar Rp. 6.112.768.936,-- mengalami kenaikkan sebesar 279, 23 \%. Sumbangan terhadap PAD Kota Palangka Raya terus mengalami peningkatan, walaupun jumlah kunjungan wisatawan relatif tidak terjadi peningkatan. Kemungkinan lama tinggal dan jumlah akomodasi yang digunakan lebih meningkat darisisi kualitas (data lama tinggal dan akomodasi tidak diperoleh).

\section{Beberapa lsu Penting Industri Pariwisata Kota Palangka Raya}

\section{Support Capacity}

Ketika pariwisata mengalami perkembangan seperti diharapkan semua pihak, ada beberapa faktor yang perlu mendapat perhatian dan penanganan yang baik, sehingga tidak menimbulkan permasalahan, tetapi justru menjadi daya dukung yang diandalkan, karena dapat memperkaya industri pariwisata itu sendiri. Beberapa daya dukung seperti, adanya resonansi yang baik, sumberdaya yang memadai, kondisi objek yang tetap menarik, tersedianya fasilitas penunjang pariwisata, situs-situs sebagai daya tarik wisatawan tetap perlu dipelihara, didukung budaya masyarakat Kota Palangka Raya yang ramah, santun yang menunjukan kepedulian terhadap pariwisata itu sendiri. Beberapa isu penting perlu dikelola dengan baik demi memertahankan eksistensi Kota Palangka Raya sebagai tujuan wisata yang tetap menarik, antara lain. perlu pengaturan resonansi yang seimbang untuk semua kawasan. 


\section{Efek Globalisasi dan Urbanisasi Masyarakat Pendatang}

Begitu semaraknya perkembangan industri pariwisata dan kehidupan di Kota Palangka Raya, sangat menarik penduduk luar masuk dan bermukim sekaligus menjadikan tempat meraih pedapatan yang layak dimata penduduk luar. Hal ini menjadikan urbaniasi dan migrasi terjadi secara besar-besaran. Pada tahun 2013 penduduk Kota Palangka Raya berjumlah 244.500 orang sebelumnya pada tahun 2009 berjumlah 200.998 orang, mengalami kenaikan sebanyak 43.502 orang atau 21,64\% selama 5 tahun. Globalisasi menunjukan hampir tidak ada batasan jarak lagi antara bangsa bangsa di dunia. Pemenuhan kebutuhan hidup dengan cepat dapat terpenuhi, berkat komunikasi yang serba cepat, lalu lintas transaksi bisnis tidak lagi mengharuskan pertemuan produsen dengan konsumen, antara pembeli dan penjual, transaksi ekonomi secara elektronik.

\section{Perubahan Kultur Masyarakat Kota Palangka Raya}

Perubahan yang signifikan sebagai imbas adanya perkembangan industri pariwisata Kota Palangka Raya, menimbulkan adanya perubahan kultur masyarakatnya. Hal ini terjadi karena adanya orientasi kehidupan masyarakat Kota Palangka Raya yang dulunya masyarakat agraris tradisional ke masyarakat agraris modern/urban, yang lebih banyak berorientasi terhadap ekonomi, dimana segala galanya diukur dengan nilai uang. Kota Palangka Raya secara umum sudah bergeser, hal ini dapat dilihat bahwa dari polarisasi kehidupan masyarakat terutama di daerah perkotaan sudah bergeser dari social oriented ke economic oriented (Wawacara dengan Kepala Dinas Kebudayaan dn Pariwisata, 2013).

\section{Analisis SWOT Industri Pariwisata Kota Palangka Raya}

\section{Formulasi Strategis Menggunakan Matriks SWOT}

\begin{tabular}{|c|c|c|}
\hline Eksternal & $\begin{array}{l}\text { Strengths/Kekuatan (S) } \\
\text { 1. Keindahan alam yang unik } \\
\text { dan eksotik } \\
\text { 2. Potensi kunjungan wisatawan } \\
\text { domestik } \\
\text { 3. Ketersediaan angkutan wisata } \\
\text { (darat/sungai) } \\
\text { 4. Tersedianya sarana akomodsi } \\
\text { yang memadai }\end{array}$ & $\begin{array}{ll}\text { Weaknesses/Kelemahan }(\mathbf{W}) \\
\text { 1. } \\
\text { Belum optimalnya } \\
\text { pemanfaatan berbagai } \\
\text { potensi objek wisata } \\
\text { 2. } \begin{array}{l}\text { Belum optimalnya } \\
\text { keterampilan MSDM/ tidak } \\
\text { dengan kebutuhan }\end{array} \\
\text { 3. Belum adanya program } \\
\text { promosi dalam dan luar } \\
\text { negri yang } \\
\text { berkesinambungan } \\
\text { 4. } \begin{array}{l}\text { Menurunnya nilai-nilai } \\
\text { budaya, tumbuhnya sikap } \\
\text { komersil. }\end{array}\end{array}$ \\
\hline 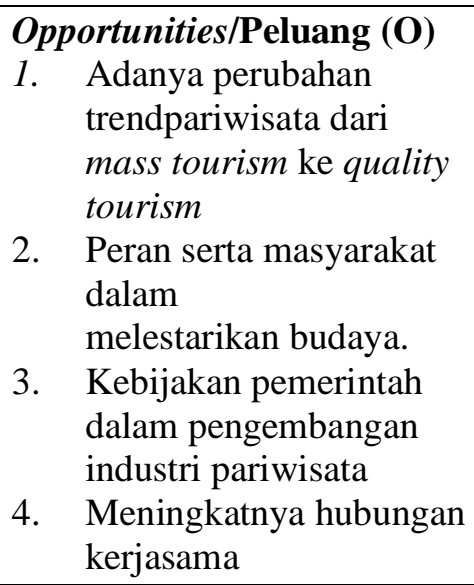 & $\begin{array}{l}\text { Strategi (S-O) } \\
\text { 1. Pengembangan strategi } \\
\text { wisata meliputi : } \\
\text { 2. Menggali potensi wisata yang } \\
\text { ada untuk di kembangkan. }\end{array}$ & $\begin{array}{l}\text { Strategi (W-O) } \\
\text { 1. Menggarap berbagai } \\
\text { potensi yang dimiliki } \\
\text { menjadikannya obyek } \\
\text { wisata alternatif,yang } \\
\text { inovatif, atraktif, dan } \\
\text { menarik } \\
\text { 2. Mengadakan promosi wisata } \\
\text { tujuan wisata } \\
\text { 3. Mengajak Tpemilik modal } \\
\text { untuk mau menanamkan } \\
\text { modalnya pada sektor } \\
\text { pariwisata }\end{array}$ \\
\hline
\end{tabular}




\begin{tabular}{|c|c|c|}
\hline $\begin{array}{l}\text { antara pelaku dan jasa } \\
\text { pariwisata }\end{array}$ & & $\begin{array}{l}\text { 4. Menjalin kerjasama dengan } \\
\text { berbagai pihak yang } \\
\text { berkompeten dalam } \\
\text { pariwisata }\end{array}$ \\
\hline $\begin{array}{l}\text { Threats/Ancaman (T) } \\
\text { 1. Saingan dari objek wisata } \\
\text { alam sejenis yang ada } \\
\text { di Kalimantan Tengah } \\
\text { 2. Perilaku masyarakat yang } \\
\text { pasif selalu memerlukan } \\
\text { stimulus/dorongan } \\
\text { dari pemerintah daerah } \\
\text { 3. Belum terbangunnaya } \\
\text { sistem industri pariwisata } \\
\text { yang melibatkan semua } \\
\text { pihak (stakeholder) } \\
\text { serta komponen masyarakat } \\
\text { yang ada. } \\
\text { Sarana transportasi umum } \\
\text { belum tersedia, harus } \\
\text { charter berpengaruh } \\
\text { terhadap biaya kunjungan. }\end{array}$ & $\begin{array}{l}\text { Strategi (S-T) } \\
\text { 1. } \text { Menawarkan berbagai potensi } \\
\text { pariwisata yang ada } \\
\text { kepada pihak luar, baik } \\
\text { kepada pihak pemerintah } \\
\text { maupun pihak swasta } \\
\text { 2. Mengadakan kunjungan } \\
\text { komparatif pada daerah- } \\
\text { daerah } \\
\text { yang memiliki karakteristik } \\
\text { potensi sejenis dan } \\
\text { lebih awal berkembang }\end{array}$ & 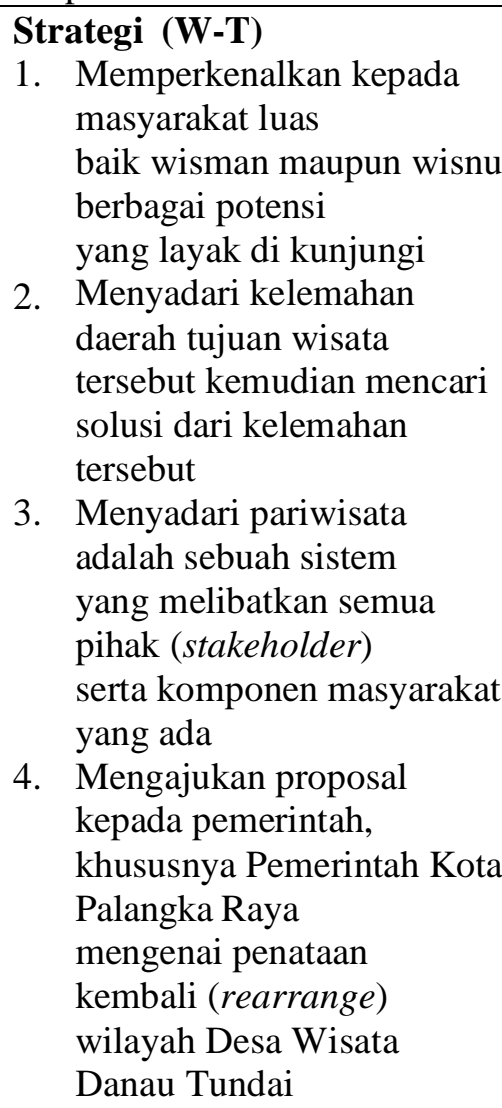 \\
\hline
\end{tabular}

\section{Kesimpulan dan Saran}

\section{Kesimpulan}

1. Industri pariwisata sebagai salah satu sumber penghasil Pendapatan Asli Daerah (PAD), merupakan potensi yang dapat dikembangkan secara berkelanjutan dimasa yag akan datang.

2. Menciptakan iklim harga murah/biaya kunjungan dan akomodasi wisata (chiff tourism), akomodasi yang murah akan menjadi daya tarik hal ini seperti yang dilakukan Vietnam dan menjadi "icon" wisatanya.

3. Melakukan kerja sama dengan semua pihak (stakeholder) dalam dan luar negeri dalam hal pemasaran/promosi, pengembangan SDM, peningkatan pengembangan kualitas fisik objek wisata.

4. Kemudahan perizinan dalam investasi dan diberikan insentif meningkatkan iklim investasi di bidang industri pariwisata bagi nvestor dalam dan luar negeri, meningkatnya pendapatan dan Return On Investmen (ROI).

\section{Saran}

1. Perlu kebijakan komprehensif dari Pemerintah Kota Palangka Raya, untuk mengarahkan seluruh sektor dan kemampuan fiskalnya dalam menumbuh dan mengembangkan sektor industri pariwisata. 
2. Pemerintah Kota Palangka Raya, dapat memberikan insentif berupa (tax holiday) atau pungutan lainnya untuk pelaku usaha di sektor industri pariwisata akan bergairah dan bermuara kepada biaya kunjungan wisata yang murah dan berkualitas.

3. Memfasilitasi bagi setiap pelaku usaha di sektor industri pariwisata untuk melakukan kerjasama dalam dan luar negri di bidang permodalan, pengetahuan, pemasaran, SDM, objek wisata yang dimiliki sehingga memiliki nilai jual sesuai selera pasar.

4. Deregulasi dalam bidang perizinan dalam investasi dan bahkan diberikan insentif untuk meningkatkan iklim investasi di sektor industri pariwisata bagi nvestor dalam dan luar negeri, lakukan sosialisasi secara komprehensif.

\section{Daftar Pustaka}

Anonim, 2000, Agenda 21 Sektor Pariwisata Untuk Pengembangan Kualitas Hidup Berkelanjutan: Proyek Agenda 21 Sektoral kerjasama Kantor Menteri Negara Lingkungan Hidup dan UNDP. Jakarta.

LPPM Universitas Udayana, 2002. Profil Kahyangan Jagat di Bali. Udayana University Press. Denpasar.

Palgunadi, 2014. Pariwisata Bali 2014, Senyum Pahit, Semyum Pahit 19 Juni 2014. Majalah Bali Post. Denpasar.

Rangkuti F., 2011. SWOT Balanced Scorcard (Teknik Menyusun Strategi Korporat yang Efektif plus Cara Mengelola Kinerja dan Risiko). Gramedia Pustaka Utama. Jakarta.

Singarimbun, Masri, dan Sofyan Effendi, 1990. Eds Metode Penelitian Survey. LP3ES, Jakarta.

2009, 2010,2011, 2012, 2013. Kota Palangka Raya Dalam Angka. Bappeda Kota Palangka Raya dan BPS Kota Palangka Raya. Palangka Raya.

2010. Undang-undang Republik Indonesia Nomor 10 Tahun 2009 tentang

Kepariwisataan, Departemen Pariwisata Seni dan Budaya. Jakarta. 